This is the accepted version of the below article which will appear in Third World

Quarterly published by Taylor and Francis:

http://www.tandfonline.com/toc/ctwq20/current

Downloaded from SOAS Research Online: http://eprints.soas.ac.uk/22111/

\title{
The South and disarmament at the UN
}

\author{
Dan Plesch*
}

\begin{abstract}
The article analyses the global South's role in disarmament. It offers the evidence of a customarily ignored Southern agency in UN processes and suggests that the work of the later Hans Morgenthau explains both this agency and contrary state policies. The article looks at the recent agreement with Iran as an example of constructive convergence and sets out the structure of an emerging and Southern-supported disarmament initiative.
\end{abstract}

Key words: disarmament; global South; Southern normative agency; United Nations; Iran

This article aims to fill a gap in the disarmament literature concerning the global South's contribution to collective efforts in UN and international circles. It also discusses the relevance of Hans Morgenthau's later work regarding analyses and politics of this issue. The essay begins with an overview of how scholars have viewed the global South's involvement in disarmament. It then discusses the current state of disarmament affairs and Morgenthau's neglected later views about it before examining in depth Southern activism. Tensions between politics and ideals precede a conclusion focusing on the possibilities for a renewed activism emanating from the global South.

\section{Academic views about the global South and disarmament}

Southern states have been important in many disarmament processes. ${ }^{1}$ Despite journals such as Third World Quarterly, International Relations (IR) as a whole, however, has given inadequate attention both to the global South and to disarmament. This can be seen as part of a generalized lack of scholarly attention to The South in World Politics. ${ }^{2}$ As Sally Morphet notes, the dynamic role of Southern countries shaping the international political agenda tends to be overlooked. ${ }^{3}$

The limitations of the concept of 'the South' as a collective noun or even just as an organised political entity pursuing common goals and sharing the same values are well known and duly acknowledged. This article does not ignore the divisions running deep among Southern countries or that common positions do not necessarily reflect common interests. However, the concept of 'the South' is useful to explore Southern individual agency in our analyses.

\footnotetext{
* Corresponding author: Email: dp27@ soas.ac..uk
} 
This article examines four academic journals (Millennium, Review of International Studies, International Studies Quarterly, and World Politics) to determine the extent to which the topic of disarmament receives scholarly attention. It fundamentally is an examination of discourse systems of signification through looking for a key term: 'disarmament' and its related and contested counterpart 'arms control'.

A survey of the Millennium illustrates the near invisibility of disarmament in the academy. This journal is especially useful for our purposes. First, it is highly regarded in IR. Second, it has a large number of articles and book reviews. Third, it has an editorial board of students that rotates each year making it less prone to editorial stasis and more open to a variety of ideas. Fourth, its theoretical perspective is generally critical and constructivist in nature tending to make it more receptive to ideas critical of established Western orthodoxy. However, the evidence demonstrates a self-imposed silence within Millennium on the subject of disarmament.

From 1971 to 2010, out of more than 4,000 articles and book reviews, only 25 included 'arms control' in the title, with 14 'disarmament' (hence, 39 in total). ${ }^{5}$ Table 1 summarises this 39 -year period. ${ }^{6}$

Table 1: Millennium

\begin{tabular}{|l|l|l|l|l|l|}
\hline & $1970 \mathrm{~s}$ & $1980 \mathrm{~s}$ & $1990 \mathrm{~s}$ & $2000 \mathrm{~s}$ & Total \\
\hline 'Arms Control' & 2 & 13 & 9 & 1 & $\mathbf{2 5}$ \\
\hline 'Disarmament' & 4 & 5 & 3 & 2 & $\mathbf{1 4}$ \\
\hline Total & $\mathbf{6}$ & $\mathbf{1 8}$ & $\mathbf{1 2}$ & $\mathbf{3}$ & $\mathbf{3 9}$ \\
\hline
\end{tabular}

However, to retain focus on the key issue here, the number of articles and book reviews is less than 1 per cent of the total articles in the journal. The near vacuum on disarmament indicates not a failure of a journal but of the discipline whose yearly ebbs and flows ensure a regular and frequent influx of what is new. Intriguingly, in 2011 a Millennium prize was awarded to an article on disarmament. However, this contemporary soloist does not fill the near silence of the previous forty years.

The critical and constructivist approaches of the journal seek to develop alternatives to mainstream realism and liberalism. Thus, it occupies a space where one might find intellectual voices that are in harmony with the view of the wider international community of states at the United Nations, especially of the General Assembly but at variance with dominant views within the major powers. A normative rationale or explanation can be found in the critique of the securitization theory of the Copenhagen School that argues that the theory creates that which it is supposed to reduce. ${ }^{7}$ In other words, it seems preferable to hope a problem goes away by ignoring it.

The same exercise was repeated with three other mainstream IR journals: Review of International Studies, International Studies Quarterly, and World Politics. The results were 
even more striking than in Millennium. Table 2 shows that the Review of International Studies published only two articles with 'arms control' in the title and two with 'disarmament' - or four pieces in almost a half-century. Table 3 documents that International Studies Quarterly in a longer period only had a total of five articles, two including 'disarmament' and three 'arms control'. Table 4 shows that World Politics, in close to seven decades, had 16 articles, eight each with 'arms control' or 'disarmament'.

Table 2: Review of International Studies

\begin{tabular}{|l|l|l|l|l|l|l|}
\hline & $1970 \mathrm{~s}$ & $1980 \mathrm{~s}$ & $1990 \mathrm{~s}$ & $2000 \mathrm{~s}$ & $2010 \mathrm{~s}$ & Total \\
\hline $\begin{array}{l}\text { 'Arms } \\
\text { Control' }\end{array}$ & 0 & 1 & 0 & 0 & 1 & $\mathbf{2}$ \\
\hline $\begin{array}{l}\text { 'Disarmament } \\
\text { Total }\end{array}$ & 0 & 0 & 0 & 2 & 0 & $\mathbf{2}$ \\
\hline
\end{tabular}

Table 3: International Studies Quarterly

\begin{tabular}{|l|l|l|l|l|l|l|l|}
\hline & $1960 \mathrm{~s}$ & $1970 \mathrm{~s}$ & $1980 \mathrm{~s}$ & $1990 \mathrm{~s}$ & $2000 \mathrm{~s}$ & $2010 \mathrm{~s}$ & Total \\
\hline $\begin{array}{l}\text { 'Arms } \\
\text { Control' }\end{array}$ & 0 & 0 & 2 & 1 & 0 & 0 & $\mathbf{3}$ \\
\hline $\begin{array}{l}\text { 'Disarmam } \\
\text { ent' }\end{array}$ & 0 & 2 & 0 & 0 & 0 & 0 & $\mathbf{2}$ \\
\hline Total & $\mathbf{0}$ & $\mathbf{2}$ & $\mathbf{2}$ & $\mathbf{1}$ & $\mathbf{0}$ & $\mathbf{0}$ & $\mathbf{5}$ \\
\hline
\end{tabular}

Table 4: World Politics

\begin{tabular}{|l|l|l|l|l|l|l|l|l|}
\hline & $1950 \mathrm{~s}$ & $1960 \mathrm{~s}$ & $1970 \mathrm{~s}$ & $1980 \mathrm{~s}$ & $1990 \mathrm{~s}$ & $2000 \mathrm{~s}$ & $2010 \mathrm{~s}$ & Total \\
\hline $\begin{array}{l}\text { 'Arms } \\
\text { Control' }\end{array}$ & 0 & 5 & 1 & 1 & 0 & 1 & 0 & $\mathbf{8}$ \\
\hline $\begin{array}{l}\text { 'Disarma } \\
\text { ment' }\end{array}$ & 2 & 5 & 0 & 0 & 1 & 0 & 0 & $\mathbf{8}$ \\
\hline Total & $\mathbf{2}$ & $\mathbf{1 0}$ & $\mathbf{1}$ & $\mathbf{1}$ & $\mathbf{1}$ & $\mathbf{1}$ & $\mathbf{0}$ & $\mathbf{1 6}$ \\
\hline
\end{tabular}

This limited attention given to disarmament by IR scholars has resulted in an intellectual gap in which the global South's role in setting the disarmament agenda and shaping UN-backed policy responses to disarmament issues have gone unnoticed. In fact, despite the intense diplomatic activity on disarmament affairs in the foreign policies of all countries, IR analysts have mainly treated the global South as a marginal and passive actor that largely reacts to changes brought about by the North rather than an agent of change influencing the conduct of world politics. The global South receives more attention in economic and development studies and postcolonial studies but not so much in security and strategic studies except for terrorism and political violence studies. 
During the Cold War, scholarly attention focused on analytical frameworks to better understand East-West political and security dynamics, which left little room for analysing the South's impact on international relations. Southern countries in this period are usually seen in terms of their affiliation with either the Western or Eastern bloc. Following this logic, their role in the conduct of world politics merely reflected the interests of their affiliated blocs and did not conceive the pursuit of separate objectives, especially with regards to disarmament. ${ }^{9}$ In other words, the countries of the global South were considered as proxies that superpowers could use as they saw fit in their deadly game of planetary chess. ${ }^{10}$ This assumption has contributed to perpetuating the idea that the global South did not count in the conduct of world politics and that Southern countries were disposable assets that were only meant to serve the North's interests. ${ }^{11}$

At the heart of this lack of academic interest in disarmament is a clear misunderstanding of achievements. Initiatives of the global South in disarmament, if at all acknowledged, are pictured as background noise coming from a crowd being mildly dissatisfied about the status quo and whose expectations are to be managed rather than taken into account by the North. Moreover, the South's perceived potential for meaningful collective action on superpowers' business was deemed negligible. However, when looked at it more closely, Morphet is closer to the mark:

[T]hrough its assertion of growing strength, particularly in the General Assembly but also the UN agencies, developing countries were able to pass seminal resolutions that effectively took the moral initiative away from the West by 'grafting' their aims within the recognised framework of universal norms. ${ }^{12}$

A more thorough study of UN disarmament policies will show that the global South has been successful in bringing its interest on disarmament into UN frameworks and influential in crafting UN disarmament policies in line with its aims, as well as generating momentum for multilateral disarmament agreements. Indeed, from the outset the global South developed its own conception of disarmament issues partly based on a sense of military vulnerability vis-à-vis the North; a common understanding that their faith, in the event of a nuclear war, was intrinsically linked as none of them could have escaped the consequences of nuclear explosions; and a common humanitarian interpretation of the principles set forth in the UN Charter. ${ }^{13}$ This was notably reflected by the first NAM statement in 1961 and its emphasis on general and complete disarmament.

This article demonstrates that Southern countries have been active in disarmament affairs and have often influenced the outcome of negotiations, thereby having an impact as the result of which Northern countries have renounced the use of certain types of weapons and indirectly reshaped military strategies and security policies. Their involvement in disarmament and weapons controls more generally, at times clashing with each other, takes different forms. Some initiatives are the result of individual efforts as shown by the Costa Rican experience with the export controlling, Arms Trade Treaty (ATT) and the leadership of the then Costa Rican president and Nobel laureate Oscar Arias, who brought the issue of arms 
trade to the UN negotiating table. Others reflect regional efforts as demonstrated by the five nuclear weapon free zones (NWFZ) treaties (Bangkok Treaty, Pelindaba Treaty, Treaty of Rarotonga, Treaty of Tlatelolco, and the Treaty on a Nuclear-Weapon-Free Zone in Central Asia), where regional groups of states have taken a legally binding decision to prohibit the emplacement of nuclear weapons on their territory. And still others reflect transnational efforts as shown by the NAM experience and the movement's continual efforts towards nuclear disarmament that contributed to the negotiation of the Comprehensive Nuclear Test Ban Treaty. All those efforts, individual or collective, initiated or followed, successful or less successful deserve more in-depth documentation and analysis.

An intriguing illustration of the implications of regional processes relates to a global political and social process concerned with nuclear war. Thus, the Latin American Treaty of Tlatelolco was profoundly influenced by the effect of the Cuban Missile crisis on regional populations and governments that had until then seen the nuclear confrontation as a USSoviet affair. In the Pacific, the impact of large numbers of nuclear test explosions in the atmosphere in the region and the influence of the Australia-set novel of the nuclear Apocalypse - On the Beach - is another case in point.

\section{The current state of disarmament}

Disarmament has been a central issue on the international agenda since the Hague Conferences of 1899 and 1907. Even after the collapse of the 1932-1934 World Disarmament Conference in Geneva and the rise of the dictators, disarmament re-appeared. It first arose in the Atlantic Charter and the UN Charter of 1941 and 1945 and in the central machinery of the UN. But much of the Cold War interstate effort remained at the superpower level, with civil society and non-nuclear states seeking to put a brake on what many saw as a race to extinction.

Since the creation of the UN, states' track records on disarmament are usually seen as insufficient and slim. This perception is partly due to the fact that the elimination of nuclear weapons, which is the subject of many General Assembly resolutions, remains a distant goal. Saying that disarmament efforts have not borne fruit and only reflect the least common denominator among negotiating states, however, leaves out important parts of the equation. A fair history would point to the fact that as of January 2016, the UN Office for Disarmament Affairs listed on its website no fewer than 25 disarmament treaties that have been negotiated since 1945. The verb 'negotiated' is not anodyne as pre-UN disarmament, with the exception of the 1925 Geneva Protocol and the naval disarmament agreements of the interwar period, was a tool of punishment imposed upon defeated countries. Within UN forums, disarmament took a different dimension and was associated with the more noble objectives of peaceful settlement of disputes and economic development. In other words, the UN provided a multilateral framework in which countries could negotiate disarmament in good faith and with a view to end human suffering caused by armed conflicts. Humanitarian motives have always underpinned disarmament efforts, and especially in the global South where citizens 
were often the victims of wars waged by competing groups armed with weapons provided by the North, and in which regimes wasted precious resources on arms rather than poverty reduction.

Even though not all of the 25 treaties were negotiated under UN auspices, almost all refer to the UN Charter and were designed as measures contributing to the realisation of the UN disarmament goals. US - Soviet agreements took place in the context of intense international debates, not least in the United Nations. Despite the progress, much remains to be done. For example, nuclear weapons, missile defence systems, hypersonic conventional weapons and new technologies are all issues that will hardly be tackled without substantial political will on all sides. However, from a purely technical perspective these, 25 treaties already provide a comprehensive set of measures that can be used to cover all types of weapons in a practical manner. Indeed, the international community of states has achieved an often overlooked tour de force of developing the necessary know-how for a global system of weapons control and disarmament. From small arms and light weapons through confidenceand security-building measures (CSBMs) to weapons of mass destruction, every aspect of disarmament can be effectively addressed by building on tried and tested achievements in disarmament, ${ }^{14}$ a topic elaborated below.

\section{Morgenthau's perspective on nuclear weapons}

Since the splitting of the atom and the bombings of Hiroshima and Nagasaki, the global South has always expressed active concern about nuclear weapons, and disarmament is a recurrent theme in all NAM declarations and in General Assembly resolutions sponsored by developing countries. The rational for Southern involvement in nuclear disarmament seems to be better captured by the late work of Hans Morgenthau. In his A New Foreign Policy for the United States, he dedicated a chapter to "Nuclear Power and Foreign Policy" in which he makes a very different argument to that attributed to him on the basis of his earlier writings. ${ }^{15}$ In this book, Morgenthau contends that:

[T] he rational relationship that existed from the beginning of history to 1945 between force as a means and the ends of foreign policy does not apply to nuclear weapons. The destructiveness of nuclear weapons is so enormous that it overwhelms all possible objectives of a rational foreign policy.... Their very existence compels us to rethink the basic issues of foreign policy. But we continue in large measure to think and act as though 1945 did not mark one of the greatest watersheds of history where a new age began. ${ }^{16}$

Thus, foreign policy cannot be conducted in a rational manner because of the existence of nuclear weapons. Their nuclear nature sets them apart from conventional weapons and renders irrational and dangerous any attempt to adapt them to an obsolete mode of thought only appropriate to conventional weapons. ${ }^{17}$ Morgenthau presents a dilemma: 
[W]e have tackled the wrong horn of the nuclear dilemma. Instead of trying in vain to assimilate nuclear power to the purposes and the instrumentalities of the nation-state, we ought to have tried to adapt these purposes and instrumentalities to the potentialities of nuclear power. ${ }^{18}$

He also sought new forms of behaviour to accommodate new nuclear realities. His post-atomic classical outlook well describes state behaviour since 1945. His enlightened postatomic perspective grapples with the pre-atomic perspectives on the edge of the precipice. The underlying reasons for the South's repeated calls and efforts towards nuclear disarmament come from Morgenthau's and others awareness of the bomb's being a gamechanger in the conduct of world politics. Hence, old conventional thinking could not be applied to nuclear weapons. In particular, nuclear powers, for the sake of their own survival, needed to embark on a programme of nuclear disarmament.

Southern concerns echo the understanding that the applicability of traditional Realism vanished with the bomb, and that states needs should thus temper their actions in a Kantian manner out of Realist necessity, a replication of the logic that drove multilateral cooperation in the wartime years and the establishment of the United Nations. ${ }^{19}$ The lack of nuclear weapons use, especially against non-nuclear states and peoples, is a seriously under-analysed phenomenon. Thucydides would have been shocked to find that the USA neither used its nuclear monopoly on the USSR nor on China. The ancients would not have flinched over using the bomb to crush the Viet Cong in Hanoi and insurgents in Fallujah fighting their US liberators. In the USA, Senator Barry Goldwater may have recommended using tactical nuclear weapons in the forests of Southeast Asia, but he lost the presidential election. And by 2001, although President George W. Bush's advisors opined that the toughest policy is the best policy, nuclear use in the Middle East was not amongst their policy options. Similarly, European states did not deal out nuclear genocide in the postwar period to discipline the natives in the manner practiced by the powerful on countless occasions back into antiquity. According to the ancient logic of force, the Soviet Union too would have considered using its nuclear weapons to bring communism to Afghanistan or to halt the implosion of the Eastern bloc.

The 1955 Russell-Einstein manifesto was originally to have been announced in New Delhi; it was the first major intellectual declaration of the ideas expressed by Morgenthau. In the tradition of naming a concept after its first and most eminent proponent, we can call this 'Einstein realism', which in fact found widespread public support across the global South as shown by the level of personal involvement from NAM leaders such as Yugoslavia's Josip Broz Tito and India's Jawaharlal Nehru who took upon themselves to bring the topic of nuclear disarmament to the international agenda-later, of course, India developed a nuclear hedge.

With the accession to the restricted nuclear club by China, India and Pakistan, the soaring rhetoric in the early NAM pronouncements might have faded away. It has not. Indeed, it is still brandished by the non-nuclear members of the global South as a rallying 
banner against nuclear weapons. Double standards are relevant, but more relevant still is the ideal deeply rooted in the global South's perception of itself and its vulnerability to the irresponsibility of a few nuclear powers, North and South.

\section{Southern activism on disarmament}

The history of activism in the global South is most effectively captured by examining a set of visible public diplomatic efforts beginning in Bandung and continuing elsewhere.

\section{The Bandung Conference}

The end of World War II and the collapse of European empires coincided with the emergence of newly independent countries that joined the ranks of well-established countries in what is now viewed as the global South. They were already vocal about disarmament issues in the 1950s, resulting in the 1955 Bandung Conference. This gathering of Asian and African countries offers insights into how the South started organizing itself as a transnational political movement and drafting a common agenda to reflect its perceived interests and concerns. Whatever their political inclinations, all countries present at Bandung were adamant about the importance of disarmament and the United Nations for the preservation of world peace and international security. In the final communiqué, states parties declared:

[T]hat universal disarmament is an absolute necessity for the preservation of peace and requested the United Nations to continue its efforts and appealed to all concerned speedily to bring about the regulation, limitation, control and reduction of all armed forces and armaments, including the prohibition of the production, experimentation and use of all weapons of mass destruction, and to control to this end. ${ }^{20}$

The rhetoric used by the South was already pointed as the countries present in April 1955 took upon themselves to lead the disarmament effort on behalf of humanity and civilisation. This early awareness of the importance of disarmament lies in the repressive colonial history of the global South. As Europe was enjoying an unprecedented period of relative peace and prosperity (1815-1914) and expanded its colonial territory to engulf some 85 per cent of the planet, colonies and even independent countries located in the global South experienced the violent military might of European colonial designs. ${ }^{21}$ From the 1856 bombardment of Canton by the UK to the 1931 Spanish aerial bombardment of Morocco, the South experienced the damage and suffering caused by heavy weaponry. ${ }^{22}$ Hence, they saw first-hand the necessity to eliminate the lethal tools developed and used by the North to impose its will and inflict harm and destruction upon weaker societies. ${ }^{23}$ Noteworthy also is the reference to the United Nations as the preferred institutional framework for tackling disarmament. Since the Western and Eastern blocs had just begun the Cold War and their conception of security was synonymous of modernizing and building up military capabilities, the global South sought to bring the North to the disarmament table; and they insisted that they be part of a joint UN effort to regulate, limit, control and reduce all armed forces and armaments. 
The declaration of the Bandung Conference was not just a well-meaning though insincere commitment to disarmament. The ideas were backed by actions. Southern involvement in disarmament affairs both preceding and following Bandung was characterised by intense activity inside the United Nations. In the early 1950s, through the First Committee of the General Assembly, the South was able to play an influential role in the adoption of the 1952 Resolution 502 (VI), which established under the Security Council a Disarmament Commission with the objectives of regulating, limiting and reducing all armed forces and all armaments - for the elimination of all major weapons adaptable to mass destruction, and for effective international control of atomic energy. Although the initial proposal was put forward by France, the United Kingdom and the United States, countries like Peru and Egypt were vocally pushed hard for the inclusion of references to the elimination of weapons of mass destruction. ${ }^{24}$ Iraq, Pakistan and Syria played a more conciliatory role in the negotiations by acting as mediators and trying to bridge the gap between the West and the East. For example, they put forward a joint proposal that was later adopted, for the establishment of a disarmament sub-committee within the Disarmament Commission as a means of scrutiny and elimination of the differences between the great powers. ${ }^{25}$

\section{The Non-Aligned Movement}

Eventually, the evolution of disarmament activism among countries of the global South took the form of the Non-Aligned Movement, which provided an ideological breakaway from the mainstream West-East thinking and the perfect vector through which the South could introduce its initiatives into the international policy arena. Following the gathering in Bandung, NAM was formerly established in 1961 at a conference in where 28 countries from the global South agreed a meaningful final communiqué. The summit stressed the paramount importance of disarmament and put it at the forefront of the group's agenda. Indeed, the first NAM declaration frames disarmament as an imperative and the most urgent task of humankind. This declaration sets out a collective agenda unanimously agreed by the participating countries about several issues deemed of vital interest. First, NAM participants adopted a comprehensive understanding of disarmament whereby general and complete disarmament meant the elimination of armed forces, armaments, foreign bases, manufacture of arms as well as elimination of institutions and installations for military training, except for purposes of internal security; and the total prohibition of the production, possession and utilization of nuclear and thermo-nuclear arms, bacteriological and chemical weapons as well as the elimination of equipment and installations for the delivery and placement and operational use of weapons of mass destruction on national territories. Second, they called upon all states, and those exploring outer space in particular, to undertake to use outer space exclusively for peaceful purposes. Third, they urged the great powers to sign without further delay a treaty for general and complete disarmament in order to save humankind from the scourge of war and to release energy and resources now being spent on armaments to be used for the peaceful economic and social development of all. Fourth, they considered that all discussions on disarmament should be held under UN auspices. Finally, they declared 
essential an agreement on the prohibition of all nuclear and thermonuclear tests and a restoration of the moratorium on the testing of all nuclear weapons. ${ }^{26}$

These points formed the core of NAM's agenda and explicitly set the priorities of the movement. The pre-eminence of disarmament as a theme of foreign policy among NAM countries reflects several factors directly linked to the issues raised in the declaration. The first factor is a common understanding that in the context of the Cold War the nuclear arms race was the primary menace facing the global South. ${ }^{27}$ Tito and Nehru among others were persuaded that in the absence of a programme of global disarmament, the two arch-rivals in Washington and Moscow would collide and bring chaos to the rest of the world. ${ }^{28}$ Indeed, at the end of the Belgrade Conference on behalf of NAM, Tito and Nehru went on a mediation mission respectively to the USA and the USSR to initiate détente between the superpowers and find ways to disarm. The economic aspect of disarmament was another factor that led NAM to engage in disarmament. Economic development was seen as the key that would extract those countries from a low-level income trap and propel them on a more prosperous path. Hence, NAM's interest was in framing disarmament and development as two sides of the same coin. It saw the arms race as a huge drain on resources and energy that could have otherwise benefit the global South through the funding of socioeconomic programmes for developing countries. ${ }^{29}$

Another factor was NAM's intention to play a more assertive role in the conduct of world politics. ${ }^{30}$ It did not want to be excluded from decision making and therefore emphasised and re-emphasised the universal United Nations as the sole international forum for disarmament. ${ }^{31}$ The NAM understood that its voice would weigh more if Southern countries were coordinated and used common channels to advance their interests. Even though the UN was characterised by asymmetric power relations - especially in the Security Council between the five permanent members and the rest - the world organisation still offered a platform on which all states were represented and, if organised in large groups, could influence the conduct of world politics. This UN potential was explored by NAM, and its members learned how to use the system to their own advantage. NAM's concern about the use of outer space and the undertaking of nuclear tests by the great powers was also a factor of its involvement in disarmament. The choice of tackling these two issues was motivated by the necessity to avoid any kind of collateral damage resulting from the modernisation of nuclear weapons. From 1945 to 1963, the nuclear powers had carried out the bulk of their nuclear tests above ground, in the atmosphere (both at sea-level and higher altitudes) and in outer space. The radioactive fall-out from those tests had obvious detrimental effects on the populations and environment close to the zone of detonations. The NAM collectively worried about side-effects and decided to pressure the nuclear powers to halt their tests. Even before the formation of NAM, in 1954, Nehru voiced its concern and proposed the prohibition of all nuclear tests worldwide. ${ }^{32}$

At the insistence of the global South, whose members saw an East-West monopoly of disarmament as undermining both their role and the UN's role on the international scene, the Ten Nation Committee on Disarmament, exclusively composed by Northern countries, was 
called upon to reform and include member states from the South. ${ }^{33}$ This reform led to the creation of the 18 Nation Committee on Disarmament (1961-1969) that included seven nonaligned or soon to be nonaligned countries: Brazil, Burma, Ethiopia, India, Mexico, Nigeria and Egypt. ${ }^{34}$ In this forum, NAM managed to successfully pursue its disarmament objectives. The first of its indirect achievements was the Partial Nuclear Test Ban Treaty signed in 1963 by the USA, USSR and UK. During the sixth meeting of the Committee on Disarmament in March 1962, Egypt, Ethiopia and Burma (later Myanmar) demanded that top priority be given to the question of stopping nuclear tests and led the debate. ${ }^{35}$ At the end of this session, the decision was to set up a sub-committee composed of the USSR, USA, and UK to consider the question of a treaty on the prohibition of nuclear weapons tests. ${ }^{36}$ It is the work done by this sub-committee, which was set up under the impetus of NAM countries that finally allowed for the signature of the 1963 Partial Nuclear Test Ban Treaty. Five years later, in 1968, NAM countries again played a significant role in another disarmament process that became a landmark disarmament treaty: the Non-Proliferation Treaty (NPT). In fact, the draft NPT jointly presented by the USA and the USSR reflected useful suggestions made by NAM members in the 18 Nation Committee on Disarmament. ${ }^{37}$ The superpower competition for NAM support provided the political space that NAM states, in concert with Western civil society and some neutral states, used to advance debate about controlling the bomb.

Since the 1960s, disarmament issues have been put on the back burner while others have been added to the NAM agenda - in particular, the establishment of nuclear weapon free zones $;{ }^{38}$ the implementation of negative security assurances; ${ }^{39}$ the use of nonproliferation measures by the North to prevent the South from acquiring and developing peaceful nuclear technology; ${ }^{40}$ the right to peaceful uses of nuclear energy; ${ }^{41}$ enhancing nuclear safety and security at facilities utilising radioactive materials; ${ }^{42}$ and the use of WMD by terrorist groups. ${ }^{43}$ Whatever the shifts in geopolitics or diverging national interests, NAM has consistently maintained its disarmament agenda and pushed for all disarmament issues identified and agreed to be brought to UN machinery and acted upon.

\section{Other Southern-led disarmament efforts}

The Argentinian-Brazilian experience in upholding nuclear disarmament is unique in the sense that two regional powers contending for the title of regional hegemon in South America have managed to transcend security concerns and renounce going down the path of nuclearisation.

South Africa stands out as a state that acquired nuclear weapons with Western assistance, refused to recognise this publicly, and with a new regime managed its unilateral elimination under international safeguards. The African National Congress did not regard retention of the bomb as a ticket to enter the UN Security Council, or acquire definitive leadership in Africa and NAM. Indeed, their position was quite the opposite.

African and Caribbean states, for their part, have contributed to reducing violence due to small arms and light weapons. The Central African Convention offers a framework for the 
control of small arms and light weapons, their ammunition and all parts and components that can be used for their manufacture, repair and assembly. The Arms Trade Treaty would not have been brought to light without the involvement and leadership shown by Caribbean States, in particular former Costa Rican president Oscar Arias continues pushing for the issue of arms transfer at the UN.

\section{Tensions between new political aspirations and old ideals}

The history of the global South and disarmament is in many respects paradoxical. Although always very sharp in their criticism of the arms race and eloquent in condemning the actions of a few Northern countries behaving according to their own rules, many Southern countries were themselves behaving in ways that contradicted the very values that they espoused on the international stage. Competing political aspirations and international ideals revolved around proposing a different world order where the North's propensity to resort to force to impose its will could be kept in check characterised the South's relationship with disarmament. In other words, diverging political interests among Southern countries and their search for regional influence and international status led certain developing countries to move away from disarmament while still supporting old liberal and internationalist visions and advocating for disarmament at the United Nations.

The 1947-1948 Indo-Pakistani War left lasting traces in South Asia and dramatically altered the security dynamics between the two major powers in the region. Afterwards both countries engaged in a sustained effort to develop their respective military capabilities with the objective to acquire the means to prevail in future conflicts. The standoff was to a certain extent similar to the West-East standoff, with two blocs or, in this particular instance, two countries, engaged in a race to build up their defensive and offensive capacities, thereby acquiring the potential to precipitate both countries into a suicidal conflict. The Indian and Pakistani disarmament rhetoric, based on the sensible argument that the arms race was the main obstacle to peace and that disarmament, would pave the way to reduce tensions and build trust simultaneously stood in stark contrast with their own actions on the ground. China's accession to the nuclear armed states club in the early 1960s and the Indian defeat in the brief Indo-Chinese war of 1962 provided India and subsequently Pakistan with further impetus for the development of the atomic bomb. ${ }^{44}$ Deterrence was the main rhetorical reason behind their acquisition of nuclear weapons, but it failed to avert the 1999 Indo-Pakistani War and repeated skirmishes on the border in 2011, 2013, 2014 and 2015. With the failure of deterrence and the impossibility of fitting nuclear weapons into a rational foreign policy, India and Pakistan were left with a weapon that put them in an awkward position. Indeed, their nuclear status, still not formally recognized by the UN Security Council, set them apart from the rest of the NAM countries and excluded them from certain UN-sponsored multilateral forums such as the NPT and the International Atomic Energy Agency. Long standing Chinese support for the Pakistan programme was mirrored by that of the USSR for India, until the George W. Bush administration set aside NPT norms and made a long-term agreement to support India's nuclear energy programme. 
The persistence of tensions and armed conflicts among countries in the global South weakened their otherwise strong moral challenge to the arms race initiated by the North. ${ }^{45}$ Although still the subject of many speeches and declarations by the global South, the noble aspiration of strengthening international security through disarmament has been the victim of the pursuit of influence and security through the accumulation of hard power. This geopolitical reality has led many to go down the path of heavy militarisation. Egypt, Syria and Iraq, to mention just a few, are all good examples of this hypocritical relationship. They vehemently protested, for example, the Israeli and South African WMD programmes, and the assistance provided by the West on the grounds that neither quantitative additions nor qualitative improvements reduced a state's vulnerability or led to absolute security, and that political objectives cannot be achieved by military means. ${ }^{46}$ Hence, they proposed the rational option to seek security for all through total nuclear disarmament, elimination of other weapons of mass destruction, and through the balanced and progressive reductions of conventional armaments at the global and regional levels. ${ }^{47}$ However, they were simultaneously pursuing covert WMD programmes, which undermined the very disarmament norms that they promoted.

This rhetorical adoption and practical rejection of disarmament compromised credibility and led to the obvious charge of hypocrisy. What was meant to be a global disarmament effort led by the global South in order to bring the nuclear powers of the North to reverse its destructive course of action turned out to be a disarmament menu à la carte from which the nuclear powers in the South could pick and choose their favourite disarmament topic and disregard others. China's possession and its half-hearted response to North Korea's development of nuclear weapons was perhaps the most obvious manifestation. While the DPKR nuclear program does represent a major hurdle in their relationship, as highlighted by China's repeated condemnations of North Korea's nuclear tests and its adoption of UN Security Council sanctions, China has always maintained a strategic partnership with the regime in Pyongyang. From that point it follows that keeping the status quo in the Korean peninsula seems more important to Beijing than upholding disarmament and nonproliferation norms and preventing a strategic ally from developing its nascent nuclear capability.

The issue of Iran's nuclear weapons potential has been one of the most publicly important issues in global politics for a quarter of a century. Iran's nuclear programme, including a full nuclear fuel cycle, was encouraged by the USA during the rule by the Shah but abruptly changed with the regime in Tehran. Amidst rumours of war against Iran by both the USA and Israel, diplomacy was derided and failed repeatedly. A Track II conversation over a number of years about the UN goal of the Middle East Nuclear and WMD Free Zone (MEWMDFZ), engaged senior officials past and present. Pessimism reigned at various points, notably after the US-UK invasion of Iraq and prior to Ariel Sharon's coma, which seemed to lead from contingency planning to practical measures. ${ }^{48}$ A fortunate juxtaposition 
of a post-Mahmoud Ahmadinejad Iran and a second term for the Barack Obama administration provided the impetus and diplomatic skill necessary to complete an agreement.

Mark Fitzpatrick has itemised ways that the agreement helps disarmament and nonproliferation. Diplomacy worked in a process that engaged the P5 and the European Union. The Security Council and the International Atomic Energy Agency worked. An enhanced verification system was created and can help in other cases. The NPT has been strengthened because its provisions provided an agreed normative context within which Iran agreed to remain and without making explicit reference to the 'right' to uranium enrichment. The Iranian agreement's provisions arguably enhanced possibilities in other diplomatic arenas including the Comprehensive Nuclear Test-Ban Treaty, the Fissile Material Cut-Off Treaty, and the MEWMDFZ. Other states in the region have a reduced incentive to pursue technologies that provide the basis for a nuclear weapons programme. Fitzpatrick concludes:

Finally, the Iran nuclear deal is a game-changer in many regards. Among other things, it showed the willingness of states to overcome animosities. Throughout my professional career, which started the year of the takeover of the American embassy in Tehran, the Islamic Republic of Iran has been the most disliked state for almost all of my countrymen and women. ${ }^{49}$

The successful outcome of the negotiations that were viewed as impossible opens the question of how this success could be built upon.

\section{Conclusion: towards a Renaissance of Southern-supported disarmament}

The global South has maintained a paradoxical relationship with disarmament. Born out of a genuine interest and an awareness of the necessity to get the great powers of the North to stop destructive arm races, disarmament was seen as a politically desirable tool to enhance the security in the South as for the nuclear weapon free zones or the partial and comprehensive test ban treaties. At times, the lofty rhetoric was also misused to justify the acquisition and development of various weapons when promises to disarm were made on the condition that other countries engaged in disarmament first. A façade of good intentions concealed the policies to accumulate more hard power could be pursued.

Although disarmament sometimes clashed with behaviour, the global South has nevertheless pushed the UN's disarmament agenda. General Assembly and Security Council resolutions on disarmament bear the South's imprint. In fact, as the North has stepped back from its disarmament commitments on various occasion - such as the US withdrawal from the Anti-Ballistic Missile Treaty and Russia's suspending participation in the Treaty on Conventional Armed Forces in Europe - the South has managed to keep disarmament goals alive at the United Nations. 
Today's political context is one in which a growing number of more lethal conventional weapons are in daily use in both civil and international wars, while an arms race continues in the Middle East and South and East Asia. Meanwhile, those states with nuclear weapons are introducing new ones. It is left to Henry Kissinger to observe that we survived the Cold War by luck and that the business-as- usual approach will produce a US-China war. $^{50}$

These dynamics alone justify new directions in policy to meet the long-standing goal of general and complete disarmament. The subject of speeches by world leaders could build upon more intensive disarmament efforts in the global South. These should include an emphasis on UN Charter Articles 11 and 26 and NPT Paragraph VI, which pave the way for the conceptualisation of a diplomatic and technical strategy founded in confidence- and security-building measures, the elimination of WMD, and the regulation and reduction of existing and future conventional weapons. A step in this direction took place under the heading of 'SCRAP. ${ }^{51}$ Fulfilling the objective of general and complete disarmament of course requires political will, but the mere existence of these options can begin to change political dynamics as looming crises are starting to drive leaders, governments and the public to search for more non-military solutions in an unstable and crisis-prone environment.

A starting point is to use best practice for the future. In the area of WMD, the Security Council mandated an inspection system on Iraq, which is now a tested and successful mechanism that states can voluntarily adhere. As such, it can fulfil the nuclear dimension of NPT Article VI, in addition drawing on the experience of the Intermediate-Range Nuclear Forces Treaty and Strategic Arms Reduction Treaties and various supplier regimes. Additionally, the provisions of CSBMs being developed in the Organization of American States and MERCOSUR (Mercado Comum do Sul) have wide applicability, as does the unexplored potential of satellite and drone imagery while land and air exercises and forces covered by the Vienna Accords could be developed to encompass both space-launch and naval forces. At the lower end of technology, one could enhance the Programme of Action on Small Arms and Light Weapons with provisions on transparency developed in the Arms Trade Treaty (ATT).

Thus, the know-how for a global system of weapons control and disarmament exists. From the United States Program for General and Complete Disarmament in a Peaceful World that was part of the John F. Kennedy administration's diplomatic response to the Berlin Wall through to the ATT and the recent Security Council resolution 2231 on the Iranian nuclear programme, the international community of states has accumulated a wealth of technical knowledge and practical procedures that ought to be exploited - in fact, much remains to be done within the mandate of past disarmament agreements. From small arms and light weapons through CSBMs to WMD, aspects of disarmament can be effectively addressed by building on tested precedents. Past agreements already provide a comprehensive set of measures that can be adjusted to cover all types of weapons in a practical manner. 
Transformative normative efforts of this sort can contribute to the original and still central mission of international relations, the prevention of global war rather than in honing the intellectual framework to fit nuclear weapons into pre-atomic models.

\section{Bibliography}

Alder, Chris, Sally Morphet, and Marco Antonio Vieira. The South in World Politics. New York: Palgrave, 2010.

Balzacq, Thierry. "The Three Faces of Securitization: Political Agency, Audience and Context", European Journal of International Relations 11 (2005): 171-201

Conference of the Eighteen-Nation Committee on Disarmament. Situation Report. Geneva: United Nations, 1968. Accessed January 7, 2016

http://search.archives.un.org/uploads/r/united-nationsarchives/7/b/9/7b9f458ffbb427a69cd69136fa27459c0dca69671a0e9738193b3c6372e1d500/S -0880-0002-09-00001.pdf

Conference of the Eighteen-Nation Committee on Disarmament. Summary of the Sixth Meeting. Geneva: United Nations, 1962.

Accessed January 7, 2016, http://search.archives.un.org/uploads/r/united-nationsarchives/8/a/c/8ac5de51044add380b81380ad03ed841468c5c04182a3c84ed996d2e8ac7467e/ S-0880-0001-06-00001.pdf

Eriksson, Johan. "Observers or Advocates?: On the Political Role of Security Analysts", Cooperation and Conflict, no. 3 (1999): 311-3

Fitzpatrick, Mark. A dozen ways the Iran deal promotes global disarmament and nonproliferation. London: International Institute for Strategic Studies, 2015.

Accessed January 7, 2016

http://www.iiss.org/en/politics\%20and\%20strategy/blogsections/2015-932e/august-c020/adozen-ways-the-iran-deal-promotes-global-disarmament-and-non-proliferation-8c1c

Institute of Foreign Affairs, Federal Democratic Republic of Nepal. Summit Declarations of Non-Aligned Movement. Kathmandu: Institute of Foreign Affairs, 2011.

Accessed January 7, 2016

http://namiran.org/wp-content/uploads/2013/04/Declarations-of-All-Previous-NAM-

$\underline{\text { Summits.pdf }}$

Jackson, Richard. The Non-Aligned at the UN and the Superpowers. New York: Praeger Publishers, 1983. 
Jaipal, Rikhi. Non-Alignment: Origins, Growth and Potential for World Peace. New Delhi: Allied Publishers Private Limited, 1987.

Milliken, Jennifer. "The Study of Discourse in International Relations: A Critique of Research and Methods." European Journal of International Relations, no. 2 (1999): 225-254

Ministry of Foreign Affairs, Republic of Indonesia. Asia-Africa Speak from Bandung. Djakarta: Ministry of Foreign Affairs, 1955.

Accessed January 7, 2016

http://franke.uchicago.edu/Final_Communique_Bandung_1955.pdf

Morgenthau, Hans. A New Foreign Policy for the United States. London: Pall Mall Press, 1969.

Mortimer, Robert. The Third World Coalition in International Politics. Boulder, Colo.: Westview Press, 1984.

Non-Aligned Movement. Tehran Declaration. Tehran: Non-Aligned Movement, 2012. Accessed January 7, 2016

http://namiran.org/Files/16thSummit/FinalDocument(NAM2012-Doc.1-Rev.2).pdf

Plesch, Dan and Kevin Miletic. "GCD: the way forward." Paper presented at the $70^{\text {th }}$ First Committee of the UN General Assembly, New York, October 21, 2015.

Plesch, Dan and Thomas G. Weiss, eds. Wartime Origins and the Future United Nations. London: Routledge, 2015.

Prashad, Vijay. The Darker Nations: A People's History of the Third World. New York: New Press, 2007.

Pubantz, Jerry, and John Allphin Moore. "Eighteen Nation Disarmament Committee (ENDC)." in Encyclopaedia of the United Nations. New York: Facts On File, Inc., 2008. Accessed January 7, 2016 http://www.fofweb.com/History/HistRefMain.asp?iPin=EUNN0133\&SID=2\&DatabaseName=Modern +World+History+Online\&InputText=\%22Eighteen+Nation+Disarmament+Committee+ENDC\%22\&Sear chStyle=\&dTitle=Eighteen+Nation+Disarmament+Committee+\%28ENDC\%29\&TabRecordType=All+Re cords \&BioCountPass $=0 \&$ SubCountPass $=2 \&$ DocCountPass $=0 \& 1 m g$ CountPass $=0 \&$ MapCountPass $=0 \& \mathrm{Fe}$ dCountPass $=\&$ MedCountPass $=0$ \&News CountPass $=0$ \&ecPosition $=1 \&$ AmericanData $=\&$ WomenData $=$ \&AFHCData $=\&$ IndianData $=\&$ WorldData $=$ Set $\&$ AncientData $=\&$ GovernmentData $=$

Riedel, Bruce. "JFK's Overshadowed Crisis.” The National Interest, July-Aug. 2012. Accessed January 7, 2016 http://nationalinterest.org/article/jfks-overshadowed-crisis-7073?page=show 
Shultz, George, William Perry, Henry Kissinger and Sam Nunn. "Deterrence in the Age of Nuclear Proliferation”, The Wall Street Journal, March 7, 2011. http://www.wsj.com/articles/SB10001424052748703300904576178760530169414

United Nations. Report to the Secretary-General, New York: United Nations, 1951. http://search.archives.un.org/uploads/r/united-nationsarchives/9/f/3/9f39703513e94771630116e76770fb1e7aaed72249073d027b0fa80a9b5229ab/S -0922-0006-01-00001.pdf

Westad, Arne. The Global Cold War: Third World Interventions and the Making of Our Times. Cambridge: Cambridge University Press, 2006.

\section{Notes}

\footnotetext{
${ }^{1}$ The author recognises the research assistance of Kevin Miletic and David Franco.

${ }^{2}$ Alden, Morphet, and Vieira, The South in Global Politics.

3 Alden et al., The South in Global Politics, 2.

4. Milliken, "The Study of Discourse," 231.
}

5. The Editorial Board at Millennium could not confirm the total number of articles and book reviews published since 1971. However, in 2003 Mark Hoffman noted that between 1971 and 2003 some 3,000 total articles and book reviews had been published, and my estimate is that by the end of 2010 Millennium surpassed the figure of 4,000 total articles and book reviews.

6 . It is worth noting that most of these appeared in book reviews as opposed to articles.

7. For further information see Eriksson (1999) andBalzacq (2005)

9. Alden et al., The South in World Politics," 9.

10. Prashad, The Darker Nations, 143.

11. Ibid., 143.

12. Alden et al., The South in World Politics," 6.

13. Ibid., 18.

14. Plesch and Miletic, "GCD: the way forward", 1.

15. Morgenthau, A New Foreign Policy”, 208.

16. Ibid., 208.

17. Ibid., 230.

18. Ibid., 240.

${ }^{19}$ Plesch and Weiss, eds., Wartime Origins and the Future United Nations.

20. Indonesian Ministry of Foreign Affairs, "Asia-Africa speak from Bandung," 167.

21. Prashad, The Darker Nations, 42.

22. Ibid.

23. Westad, The Global Cold War, 100.

24. United Nations General Assembly, "Report to the Secretary-General," 1-33.

25.Ibid.,

26. Nepali Institute of Foreign Affairs, "Summit Declarations of NAM,"3-4.

27. Mortimer, The Third World Coalition, 14.

28. Jaipal, Non-Alignment, 68.

29. Jackson, The Non-Aligned, 172.

30. Jaipal, Non-Alignment, 72.

31. Jackson, The Non-Aligned, 172.

32. Prashad, The Darker Nations, 43. 
33. Pubantz and Moore, "Eighteen Nation Disarmament Committee", 3.

34. Ibid., 3.

35. Conference of the Eighteen-Nation Committee on Disarmament, "Summary of the Sixth Meeting," 1.

36. Conference of the Eighteen-Nation Committee on Disarmament, "Summary of the Sixth Meeting," 5.

37. Conference of the Eighteen-Nation Committee on Disarmament, "Situation Report," 29.

38. Nepali Institute of Foreign Affairs, "Summit Declarations of NAM," 20.

39. Ibid., 110.

40. Ibid., 175.

41. Ibid., .

42. Ibid., 371.

43. $16^{\text {th }}$ Summit of NAM, "Tehran Declaration", 67.

44. Riedel, "JFK's Overshadowed Crisis", 1.

45. Prashad, The Darker Nations, 43.

46. Nepali Institute of Foreign Affairs, "Summit Declarations of NAM," 206.

47. Ibid., 263.

${ }^{48}$ For details, see http://www.cisd.soas.ac.uk/substrand/middle-east-wmd-free-zoneproject, 57101077

${ }^{49}$ Fitzpatrick, "Iran deal promotes global disarmament,"1.

${ }^{50}$ Shultz et al., "Deterrence in the Age of Nuclear Proliferation", 1.

${ }^{51}$ The SCRAP concept was first introduced at the UN by SOAS researchers with the support of Costa Rica and the Philippines. Subsequently it was presented to the UN Conference on Disarmament and on the margins of the NPT Review Conference and the General Assembly's First Committee with the support of a dozen European, Latin American and Asian countries. For details, see scrapweapons.com. 